\title{
STUDENTS PERSONALITY DEVELOPMENT THROUGH INDIVIDUAL ACTION RESEARCH
}

\author{
a BOHDANA RICHTEROVÁ, 'bARBARA NEDVÍDKOVÁ \\ University of Ostrava, Faculty of Educationn, Fráni Šrámka 3, \\ Ostrava, Czech republic \\ email: ${ }^{a}$ bohdana.richterova@osu.cz, ${ }^{b}$ d19404@student.osu.cz
} The article was supported by a Grant Agency SGS 6114 Using the Personal Action
Research Journal (PARJ) as a Tool of Professional Development of Social Education Students

Abstract: The paper presents a student project. Ten students of the Pedagogy Faculty crried out individual action research in different areas of social and persoctity carried out individual action research in different areas of social and personality development in the years 2019-2020. The aim of the paper is to present the project, its (1988) was whod with. Four-phase model of action rese topics were identifed, all focused on development. communication skills improvement, selfvalue and self-trust improvement, facing demanding situations and work with escape strategies, skills of appropriate response in conflict situations, diminishing fear of entering new situations and work with negative evaluation of other people. An example of a chosen research presents the work of a student in action research phases focusing on work with stress.

Keywords: individual action research, four-phase model of action research, pedagogy faculty student, personality and social development.

\section{Introduction}

Papers focusing on methodology and conducting action research in the field of education come across the information that even though action research can be primarily focused on other areas than social personality development, it enables and encourages this very area of educators' development (eg. Mertler, 2006; Willis and Edwards, 2014). The paper introduces a student project of a particular university research aimed at conducting students' individual action research. Ten students of the followup masters programme at Pedagogy Faculty carried out individual action research in the years 2019-2020, the research tackled key issues needed for personality and social competence development. Two academic workers participated in the project apart from the students. One of the workers specialized in research methodology and organization, the other was an expert in psychological consultation with students in individual research phases, and he also worked with psychological pretests and posttests.

Selective courses with emphasis on theoretical subjects are the basis of teachers' preparation during university studies in the Czech Republic (National Accreditation Bureau, 2017). Personality and social development courses are the key for gaining the necessary personal and social competencies. Individual action research that students carried out in the project included both theoretical elements (eg. in the Plan phase - the analysis of literature regarding the research problem) as well as practical - self-experience (eg. in the Action phase students tested new procedures in problematic areas in their personal and professional lives). The project included several compulsory activities, the others were optional, and students took part in them only after the problematic area data analysis. This paper will present these activities, methodology as well as the chosen research problems that the students worked on. In the second part of the paper Barbara Nedvídková (the co-author of this paper) presents her working with stress in different phases of the action research. Both the benefits and limits of this paper are concluded at the end.

\section{Students project introduction}

The principal goal of the pregradual education of teachers is the development of key competencies. The method of lectures and presentation does not seem to be the most effective form for gaining these competencies. Most authors think that they can only be adopted by experience, training, and targeted communication development (eg. Lleó et al., 2017). The student project consisted of several elements with the above-mentioned emphasis, which formed the basic program that the involved students participated in. Furthermore, they worked on their own individual action research focused on their needs of personality and social development. They identified their needs after taking part in the programme and analysing the information gained by data collection.

The main programme included a week-long self-experience stay in the role of a client of a therapeutic community for drug addicts, participation in five focus groups focusing on personality development, a session with a psychologist and counsellor both in the therapeutic community, at the university or in another facility, and targeted interviews with close people and wiritng a personal action research journal. The students reflected their experience with a personality or social situation in their lives, they reflected their engagement in individual parts of the programme. Writing the journal and practice reflection is a way how a teacher can access their own personality development and get feedback from their practice (comp. Walker-Floyd, 2011).

Each student chose two to three key issues based on the categories which rose from the journal analysis, then they worked with them in action research cycles. During two years of action research, six key development issues were identified: communication skills improvement, self-value and self-trust strengthening, strain situation management and work with escape strategies, skills to deal with conflict situations appropriately, diminishing fear of facing new situations and work with negative judging of other people.

„Improving the communication skills includes also some narrowed research problems such as fighting the fear of speaking in front of other people and the ability to communicate negative feedback and improvement in counselling sessions management. All these issues were interconnected not only by the student personal needs but also by the need of developing teachers'competences.

The issue "Self-value and self-trust strengthening" was narrowed so that it was realistic to work with it within the time limit of one semester. Mertler (2006) suggests that if the issue is not narrowed, the work can be demotivated for the researchers and the progress is hardly observable. The narrowed topics included research problems focused on safety needs, realizing strength and strengthening self-value, professional boundaries, and working with emotional self-acceptance.

The students defined two escape strategies in the area of "Coping with strain situations and work with escape strategies" in the first year. The strategies emerged from the analysis of personal journals. During the individual action research, they decided to work to escape the strategies of crying and illness. Work on stress, emotion, procrastination, and hopelessness was covered in the second year.

The fourth topic "Gaining the skills of appropriate dealing with conflict situations" proved to be common for all students in the first year of the research. Two of them chose the narrowed topic work with emotions and constructive arguments.

"Diminishing the fear of facing new situations and improving the process of adaptation in the new environment" was chosen by one student. The possibility to involve in the therapeutic community in the role of client provided the possibility to test new strategies in the Action phase. The last identified issue "working with negative judging of other people" revealed close connections with self-acceptance and self-evaluation.

The data collection method that the students used in "Communication skills improvement" was feedback from other student close people but also from the clients of the therapeutic community where they were involved in the role of clients during the first stage of the treatment. Literature, which is well accessible in the Czech environment, helped them to make 
development plans. In the "Action" phase, they used a large range of cognitive behavioral techniques and already after the first action research cycle they noticed progress and improvement which was reflected by their environment.

In the area of "Strengthening self-value and self-trust" the students used discussions in focus groups aimed at personality development. They gained valuable feedback during this week of intense self-experience internship in the therapeutic community for drug addicts. They could reflect their thoughts in a personal action research journal.

As for the area "Defining personal boundaries" one student made a note in her journal that when she tried to define her professional and personal boundaries, she admitted she had a problem in this field. She started to think about the situation she was facing. As it was a short-term period, the close people feedback analysis did not monitor any significant changes. The progress remained only on the level of student's personal perception (personal journal notes analysis.).

Following the analysis of their personal journal notes, two students realized what their escape strategies from the strain situations are. One of them escaped into crying, the other one into illness. Both students used an analytical approach. They returned to the situations that they had experienced before and took notes in their journals. The student distinguished between different types of crying when analysing her escape into crying. She realized that she does not want to use the manipulative cry any more. Part of the action research cycle work was identifying the situations when she uses this type of crying and its refusal as soon as she understood this behaviour strategy. On contrary, the cry, which is characteristic for the student and which completes her emotional experience was accepted by her as part of her personality and individuality. The student presented the outcomes of this individual research in her thesis defence (Hutyrová, 2020).

Two students analysed conflict situations and their coping. Both described their dissatisfaction with their behaviour in these situations. The conflict did not enable them to experience stress relief but triggered depressive and melancholic moods which they did not see a way out from. After careful analysis, both students used the constructive argument theory by Kratochvíl (2009) and tried to apply it in practice. They involved their partners in the "Action" phase and tested the theory principles with them. In case of one of the students coping with difficult situations led to crossing personal boundaries and disturbing self-respect.

Literature was the valuable means in perceiving the worsened adaptation in the new environment and leading to the possibility of its improvement. The students took advantage of this to create developing plans and chose the activities that she applied and reflected.

\section{Methodology}

There is a number of action research models (eg. Richterová et al., 2020). The action research model according to Kemmis, McTaggart (1988) and Seymour-Rolls, Hughes (1998) was chosen to carry out individual action research focused on personality and social development. This model consists of four phases. It was chosen for its simplicity and comprehensibility and for its flexibility and efficacy of the phases corresponding to the chosen issue. This type of research enables to end the research in any cycle which was an important deciding factor. Not every cycle must necessarily end with the last ie. fourth phase (Willis and Edwards, 2014). Every action research model highlights not only the possibility of working in cycles, but also in a spiral. It is advisable to go through the cycle several times and bear in mind the constant need of improvement and evaluation. It is also important to end the research in the given time (Willis and Edwards, 2014).

Individual action researches conducted in this project were based on an interpretative paradigm which influences the research problem choice, data collection method, and their analysis. It defines the output interpretation and work with results. Gained results cannot be generalized but are only valid for the researched situation in the given context (Willis and Edwards, 2014).

The first phase of the action research in this model is called Reflection. In this phase, we gather information about the issue. A broad research problem is set and further it is gradually narrowed down. The researcher is the researched person at the same time in a large number of individual action researches. This is the reason it is important to involve other people, eg. other people reflection or psychological test application, etc.

The second phase is called Plan. The essential part of this phase is exploring how to tackle the problem and create the so-called developing plan. This happens based on the collected data and information analysis. Making a plan and theory is an essential part of this phase as it will encourage innovative ways of tackling the problem. The researcher should not take over a theory that somebody has already come up with, but they should be inspired and apply it to their needs.

The third phase is Action. The plan or theory which was made in the previous phase is applied in this phase. The authors call the last phase Observation. The change is observed, evaluated, and reflected. Data and information are collected again. These can be both qualitative (eg. unstructured observations or semistructured interview) or quantitative (eg. questionnaire, psychological structured test). Qualitative interpretation without any generalization is important in our case. Reflection helps to describe the progress which was made. Ideally, the results of one cycle should lead to starting a new cycle where a new developing plan and its application and evaluation happens. Only rarely are the initial changes sufficient improvements, and changes should be made (comp. eg. Willis and Edwards, 2014).

To ensure validity and reliability, several data and information collection methods were used in the individual action research. The so-called triangulation of data collection method occurred. Personal action research journal was the main research method. The term "personal action research journal" (PARJ) came to life during Walker-Floyed'research work (2011). The author focused his work on his teaching practice, he analysed his professional experience while taking notes, later he included his colleagues professional experience too. New theory was formulated and used in practice by teachers and followingly evaluated. PARJ requires that the researchers test new theories choosing innovative processes. Furthermore, they are assessed for their purposefulness (Willis and Edwards, 2014). Open coding, categories forming, and sometimes topic analysis were used to analyze the students' journals.

The questionnaire Scale of Psychological Wellbeing was an important research method. It is a standardized questionnaire made by Carol Ryff. The questionnare can be divided into six dimensions of mental well-being; self-acceptance, positive relations with others, autonomy, purpose in life, environmental mastery, and personal growth (Ryff, 1989). The students involved in the project completed the questionnare twice, and their close people did the same. For the first time, they filled it in when entering the project, for the second time after finishing the individual action plan. A project psychologist analysed the questionnaire and provided the students with feedback which they reflected in PARJ.

Other methods used by students were their own questionnaires and interviews. The interviews were mostly semistructured, they completed the data collection with chosen issues and research problems that the students addressed. The interviews were led with close people, classmates, workmates, therapeutic community workers, and clients. The interviews were recorded, transcripted, and analysed by means of open coding.

Focus groups were used as the intervention method. Some students used focus groups as an intervention method. Focus groups' issues were chosen by the group moderator or they were 
voted for by group members. Video recording was made from the focus group sessions. All involved students had access to the recording regarding the research problems, parts of the focus groups were transcripted and analyzed by open coding.

Individual phases and action research cycles were narrated by the students. The narration is based on authenticity when each narrator choses a different narration structure. Narration is a technique which takes over some tools from other scientific disciplines, such as linguistics and its metafor use, etc. (in Švaříček, Šed'ová et al., 2014). Another chapter defines the research problem and work in action research cycles as it was registered by Barbara Nedvídková.

\section{Work with stress - work in action research cycles}

The student took notes in the PARJ about all the situations which led to her dissatisfaction with her behaviour during the three months. The notes coding and categorization followed. The category "My work with stress" was significant. The student worked with this category in her work in individual action research phases and cycles. She starts her description with defining the research problem and tries to set it in wider circumstances. Research questions follow, she focuses on them in all the action research phases.

The word stress is known to everybody, its presence constantly increases. One of the indicators is the growing number of antidepressants use in the Czech Republic and has become a common problem at this time: "...the most tragic impact is on those individuals who do not speak about stress and make a considerable effort to mask it” (Novák, 2004, p. 77).

"Using my self, my personality as a therapeutic tool" is important in helping professions (Mátel, 2019, p. 150) incl. social work "...it is important that the social worker can use and cultivate his personality, his self when doing social work" (Mátel, 2019, p. 104). Getting to know one's self, selfacceptance are important parts of the process as a basis for selfrespect (Mátel, 2019, p. 104)

The aim of my research is to determine which techniques and work processes help me to cope with stress situations better. In the Reflection phase, I am going to find the most common stressors and see which ones occur with me most frequently. I am going to use psychological tests and analyse the PARJ. I am going to focus on partial research questions: What are the most frequent situations stressing me? What are my physical and mental responses to stress? How sensitive am I to stress?

The Journal analyses will help me to find answers to the first two partial questions. The answer to the last formulated partial research question in the Reflection phase will be found by means of the standardized psychological test "Coping strategy" (Nowack, 2006) and Myers-Briggs type indicator (MBTI).

In the Plan phase, I am going to analyze the literature and seek new possibilities of techniques and processes of coping with my stress. I am going to test these techniques in the Action phase. Observation phase will help me to find changes and behavioral progress and experience in stress situations.

\subsection{Reflection phase}

Stress was the very first issue in the first record in PARJ. I am going to describe a situation which I was facing at work and I later classified it as the most frequent stress evoking situation. "What if they ask me something? What if they tell me a joke which I will not understand? What if they ask me about something from life?" (D1, 1g - code: Conversation with a director creating stress). Stress does not occur only at work, but there is often time pressure at work or school, which I classify among the most frequent situations creating stress. I am going to present an example which illustrates the above mentioned. "They automatically thought that I had passed the test and therefore my brief response no was taken for a joke. In my thoughts I laughed ironically, at the same time I cast anger towards my colleague, mainly Veronika who has been the newest among our colleagues, she attends very spontaneously and moreover it is necessary to do the work for her" (D6,4i - code: Sarcasms covering anger/sadness due to failure.). Another stress evoking situation was when something unexpected happened. As an example, I will cite my PARJ notes about my father's visit to the hometown after I have not seen him for many years. "When I was calling my Mum, I started crying. On one hand I felt sorry, on the other hand I was upset. I did not want to be weak, it was all supported by the unexpected which always leads to stress and nervousness" (D4, 3i - code: fear, anger, and uncertainity manifested in cry). I would like to mention my test results from Myers Briggs Type Indicator (MBTI) where my personality type was ISTJ. This is closely connected with my finding noted in the PARJ. These people "need firm plans, clear instructions, and understandable goals. Under these conditions, they are the most effective. Unknown things and uncertain future can trigger stress in them."

To demonstrate my physical and mental responses to stress, I will quote several sentences from my journal. "Stress, anxiety, the regular need for going to the bathroom come in small, gradually increasing doses, unstoppable trembling makes me nervous and upset" (D3, 2e - code: anxiety, bathroom going and trembling as stress symptoms). “...along with fear and anxiety I am trembling, my limbs do not fill with blood ...” (D3, 2i - code: Cold as a stress symptom.). I noticed the following in my work environment: "After she left, my heartbeat was so fast that I was thinking it could jump out and slap me for stress ...” (D8, 2g code: palpitation/thoughts as response to shame).

My sensitivity to stress can be seen in the questionnaire. The results of MBTI say I am an introvert but I present myself as an extrovert. The ISTJ type can programme themselves because of their extrovercy, although loneliness is comfortable being in a company is a pleasant change and relafaxtion for me. This is conditioned by certain rules which are: a small number of people, close people, suitable repetition in the right timing is in free time. If we want to give an example from the journal, we can mention meeting the psychologist for the first time, here I demonstrate the stress of meeting a stranger "...there were only two of us, I was getting red in face ...”, “...I was on the verge of hysteria ...” (D10, 2c - code: Inner panic evoked by the unknown.). The results of the Stress profile questionnaire (Nowack, 2006) helped me to understand which coping strategies I resort to and which I should learn. Score $60 \mathrm{~T}$ and up represents frequent use of the strategy and vice versa the score 40 and lower represents minimum or missing skills in strategy use (Nowack, 2006, pp. 25-26). I had the highest score 73T in the field of Negative Appraisal. "People using this strategy come to terms with this issue when they concentrate on the worst aspects or possible consequences" (Nowack, 2006, p. 25). On the contrary, a very low score can be found in mental well being $27 \mathrm{~T}$ and $33 \mathrm{~T}$ threat minimalizing. The similarity with life experience clearly shows which strategies are strong, helpful and which are beneficial to learn and improve.

\subsection{Plan phase}

There are countless possibilities and techniques how to cope with stress, I chose the following authors Paulík (2010), Šauerová (2018), Praško and Prašková (2001), Mühlfeit and Costi (2017). Coping strategies can be divided into cognitivebehavioral approach and strategic approach and relaxation active and passive approaches.

Cognitive-behavioral techniques are, for example, trivialisation which is demonstrated by an example: "I will say to myself: It is not that bad!” (Praško and Prašková, 2001, p. 66) and distract "think about something else" (Praško and Prašková, 2001, p. $66)$. My thoughts, ideas, and preparations often result in physical and mental stress. I would like to try to push these thoughts away and these strategies are possible tools. Praško and Prašková (2001) recommend to avoid automatic negative thoughts, but my score in the Stress profile questionnaire 
(Nowack, 2006) was 73T in the field of Negative Appraisal. When we put the facts together, my best strategy results in "...postponing unpleasant things, giving up on things, resignation and sadness, and feelings of helplessness. Generally, they are overrated and evaluate themselves, their environment or future negatively”. (Praško and Prašková, 2001, p. 23). I decided to focus on the Negative Appraisal in the Action phase using the above mentioned techniques.

When studying the detailed plan for overcoming stress by Praško and Prašková (2001), we come across the strategic approach. It includes seven points and can be completed by Paulík (2010). The important thing is to get rid of inconvenient habits such as "creating excessive pressure on oneself by stressing what we have to do or what we must not do" (Paulík, 2010, p. 185). Active and passive relaxation can be used in prevention form or fight against stress as they eliminate natural stress hormones and metabolise energy accumulated by stress (Praško and Prašková, 2001, p. 61).

One of the most important and often overlooked strategies is sleep. It is a passive form of relaxation which requires keeping certain rules. The rules can be found in Paulík (2010), Mühlfeit and Costi (2017) who claim that, "...The more stressful our life is, the more sleep we need” (Mühlfeit and Costi, 2017, p. 240). As the quality sleep strategy occurs in many publications, I am going to focus on it and observe it in the action phase. Yoga is also among the relaxation techniques. It is considered "lower personality components shrinking and elucidation consciousness cleansing (átman) identification with absolute ultimate knowledge (brahma)" (Paulík, 2010, p. 195) and it is "the basis of some other relaxation techniques (eg., autogenic training, progressive muscular relaxation)” (Šauerová, 2018, p. 141). I find her multifunctionality attractive, I am going to watch if there are any changes in the regularity of stress occurrence, when leaving it out or when it is absent. According to Paulík (2010), Mühlfeit and Costi (2017), there are countless benefits of movement. Šauerová (2018) states that “...movement affects psyche anxiolytically, antidepressively and it helps to unwind" (Šauerová, 2018, p. 77). The last strategy in the action phase will be movement as I am fond of movement and I am interested to learn if this strategy is effective.

\subsection{Action Phase}

Chosen strategies were tested from May 2020. I expected that downplaying will lead to suppressing negative thoughts when I push positive thoughts forth in their place. Unfortunately, the opposite was found through reflection and I noted it down in the journal. “...I deliberately used it, but unintentionally I overlayed it by imagining the situation and that was a mistake" (D21, 6u code: unintentional overlaying of "downplaying" strategy by imagining an ideal encounter). "The downplaying strategy had no chance to succeed, but it helped me to understand that imagining the ideal leads me into even greater stress. Playing the encounter, I am getting myself into a stressful situation and therefore the negative body and mind responses get worse" (D21, 6v - code: Realizing negative impact and stress encouragement when playing the stressful situation). This fact was confirmed when using the same strategy two months later. "The downplay strategy which was used to welcome others in the meeting room was followed by stress what I am going to say. I cannot say that the results of my behaviour are only thanks to the strategy. The speech was neither terrible nor calm, and worse reset might have been caused by thinking about the contents of my speech" (D25, 8z - code: thoughts, ideas as a cause of unused potential of the downplay strategy).

The downplay strategy as well as distraction should have relieved and minimized stress. The principal was to think about something else and distract attention from stress manifestations. This was the greatest success. The same day when I used the downplay, I also used the attention distraction strategy. "The second strategy used the same day was the distraction of attention. It was used correctly and was not influenced by anything. The stress was relieved and the body and mind were progressed into the situation where they could not respond." (D25, 8ab - code: OP strategy's use by minimizing stress and moving on). It repeatedly met my expectations and I also realized its short life. "We had to adopt fast in the situation we found ourselves in and act. There was no time to stress out" (D25, 8ac - code: OP strategy leading to inability to respond to stress). I adopted to it and learned how to act. "At the time when the body calms down, it is time to face what scares us or progress somehow. Before our mind starts to occupy itself with something and before it starts all over again" (D23, 6r - code: Short term OP strategy leading to fast moving on). The initiative was an unexpected side effect of the strategy.

I will mention two key findings. Firstly, that the most effective distraction of attention is speaking to the person as it occupies all our senses. Focusing on the person is not the same thing although. "Her presence absorbed me and I concentrated fully on her. On her needs, communication and adaptation course" (D30, $1 \mathrm{~g}$ - code: Nela's presence as the most intense during OP strategy). Second finding is the bias. It is important to be totally absorbed so that negative thoughts are efficiently suppressed. I realized it and had to change the strategy. "...If it is insufficient, there must be a change made or something must be added. I had to make a porridge and watch a video, just porridge was not enough" (D30, 3u - code: Insufficient involvement leading to subconscious stress comeback.).

Other techniques to fight stress were yoga, exercise, and sleep. These are activities which occur together with prevention, but they are difficult to spot as for their efficiency and influence. The regularity in practicing yoga since May brought the finding that breaking the routine can lead to another issue: Response in heat of passion and sleep can hardly be documented. As for exercise in one of the journals, I came to the conclusion "that movement is helpful to relieve stress, but in my case, it is not about regular exercise requiring concentration on movement and muscles" (D28, 5y - code: Rhythmic exercise leading to stress relief). Another finding was “...that I cannot destress by moving in the situation when coping with the difficult situation is within reach" (D28, 5z - code: The unsolved dilemma which can be coped with immediately is not solid by exercise.). "First, I have to cope with it so that it does not keep provoking in my head and then I exercise to get rid of tremble, excessive energy, stiffness. In this case I do cardio with music. Just rhythm and movement." (D28, 5aa - code: Rhythmic activity drives trembling and stiffness away.). My last strategy was avoiding negative thinking. I used it assuming that when I realize that negative thinking increases my stress, then I win over my emotions, the opposite turns out to be true. "Avoiding negative thinking such as „I am totally impossible how I tremble I will have my intestinies bubbling I will be flatulent, I will be in pain and will be forced to relieve myslef, I am not able to lie for four hours without faux pas..." this is difficult as the authors of the book Proti stresu krok za krokem. I only supported my stress by this" (D23, 2c - code: Confirming the negative which strengthens stress from negative thinking).

\subsection{Observation Phase}

I am going to evaluate the techniques I chose in the following part, they come from individual action research journal In the Observation phase other data collection methods were used to increase the validity.

I consider attention distraction to be the most successful. The honesty in repetition enabled using the technique and revealed the negatives and strengthened the positives. The initiative is a side effect as it is very low in my case which is confirmed by the Psychological Well-Being Scales (Ryff). I had score 8 in the Autonomy dimension (AU) in January 2020, the population average was 15,2 . "...The first time the result surprised me. As soon as I could, I jumped from the technique right into speaking” (D27, 6x - code: Surprising initiative after using OP technique). Initiative acting a month later can be considered a success, as it led to personality development. At that time, I was participating in the therapeutic community FIDES, where I used 
my questionnaires. Closed questions were assessed on a bipolar scale "I seem to be stressed" up to 7th grade "I do not seem to be stressed" the average answer was 4.7. When comparing stress perception and inner feelings, they contradict each other. "Already 10 minutes before arrival I felt anxiety, my stomach was in knots, my intestinies were moving, my mouth and lips were dry. I started trembling, my feet were cold and I started to speak as the arrival was getting close ..." (D25, 1b - code: Starting stress in the form of anxiety, stomach in knots, intestines, dry mouth, cold feet, and ridiculous laugh). I think we can partly attribute the difference to the technique and partly to the unconscious strength caused by the contact with a close person. "When near Nela it was not so unbearable. She calmed my mind and gave me a feeling of the familiar. She brought in certainity, stability, and memories of home" (D26, 6m - code: Nela bringing peace, safety, stability, and memories of home). Furthermore, I found that the important part is also the intensity of involvement, the most effective of which is a close person. We have to count with short-term effect so "When the body calms down we have to face what scares us or progress somehow. We have to do it before our mind fills with the same and it all starts over again." (D23, 6r - code: Short term OP technique leading to stepping forward.).

The downplay technique had short-term effects just like the above mentioned, attention distraction technique. Its principle was to suppress negative thoughts and replace them with positive ones. I noted down in my PARJ: "learned, rigid behaviour won" (D21, 4p - code: The downplay technique is not able to suppress stereotyped behaviour.). Using both techniques showed that my strongly negative appraisal of things (see the Stress Coping Strategy test results) cannot be overcome just by using cognitive-behavioral techniques.

My other techniques were sleep and yoga. I underestimated the analysis except short notes in my individual journal. Their contribution can be neither confirmed nor disproved, nonetheless I have no doubt about their importance. The last to be evaluated is the exercise. Wholesome effects mentioned in the literature and the positive attitude to movement convinced me to try it. To sum up "Cardio with music is definitely a good way to relieve stress" (D28, 3u - Cardio with music is definitely a good way to relieve stress), "but concentrated exercise is not. It strengthened my stress ..." (D28, 3v - Concentrated exercise with elements of heat of passion finished by a shower). I also found out that usolved inner conflict cannot be avoided, that is "It's a real pain until I push it away" (D28, 4x - code: I tis a real pain until it is solved.) and then I can relieve the stress by exercise.

\section{Conclusion}

It is important to conclude with the limits of individual action research focused on personality and social development. One of the benefits but at the same time limit is the role of the researcher and respondent in one person. The student in the role of the researcher considers data collection methods which will be the least burdened by one angle of view and will make studying the reality possible. In the moment of qualitative data analysis, personal experience and individual students'view of the world enters the process. Although the analyses of the interview or tests reveal new realities, the student includes their reality perception in the qualitative interpretation. On the other hand, the benefit of this research is student's motivation to get involved in the issues which they regard important for themselves as they are interested in improving the reality. The imposibility to see and perceive certain things which remain hidden is a limitation. Although all students tried to triangulate the data collection method and their analysis, this needs to be mentioned as a limit too. Personal action research journal was the key method for all students. Interviews with close people or clients in the therapeutic community enabled to complete information for "Reflection" and "Observation” phases. Quality data collection tools such as pretests and posttests would be needed to state unequivocal progress.
One of the most beneficial progress of the research is the personal narrowing of the research of each student on their own issues. The two-year project proves the need and interest of students to improve their competencies in social and personality development. The concept of general study plans of individual programmes gains new dimensions focused on the development of the needs of each individual student.

\section{Literature:}

1. Hutyrová, M.: Akční výzkum jako nástroj osobnostního a profesního rozvoje. Master thesis. Ostrava: Faculty of Education, University of Ostrava, 2020.112 p.

2. Kemmis, S., McTaggart, R..: The Action Research Planner: Action research and the critical analysis of pedagogy, 3rd eddition. Geelong: Deaking University Press, 1988. 154 p. 3. Kratochvíl, S.: Manželská a párová terapie. Praha: Portál, 2009. 280 p. ISBN 978-80-7367-646-9.

4. Lleó, A.et al.: Mentoring Programme based on Competency Development at a Spanish University: An Action Research Study [Online]. European Journal of Engineering Education, 43(5), 2017, 706-724. https://doi.org/10.1080/03043797.2017.1 415298.

5. Mátel, A.: Teorie sociální práce I: sociální práce jako profese, akademická disciplína a védní obor. Praha: Grada, 2019. 208 p. ISBN 978-80-271-2220-2.

6. Mertler, C. A.: Action Research: Teachers as Researchers in the Classroom. California, USA: Sage Publications, 2006. 250 p. ISBN 0-7619-2844-8.

7. Mühlfeit, J., Costi, M.: Pozitivní leader: jak energie a štěstí pohánějí špičkové týmy na cestě $\mathrm{k}$ úspěchu. Brno: Management Press, 2017. 368 p. ISBN 978-80-265-0591-4.

8. National Accreditaion Burearu. Doporučené postupy pro připravu studijních programů. Praha: NAÚ, 2017. 48 p.

9. Novák, T.: Jak bojovat se stresem. Praha: Grada, 2004. 139 p. ISBN 80-247-0695-4.

10. Nowack, K. M.: Stress Profile. Praha: Hogrefe Testcentrum, 2006.

11. Paulík, K.: Psychologie lidské odolnosti. Praha: Grada, 2010. 240 p. ISBN 978-80-247-2959-6.

12. Praško, J., Prašková, H.: Proti stresu krok za krokem. Praha: Grada, 2001. 201 p. ISBN 80-247-0068-9.

13. Richterová, B. et al.: Akční výzkum v teorii a praxi. Ostrava: Pedagogická fakulta Ostravské univerzity, 2020. 199 p. ISBN 978-80-7599-176-8.

14. Ryff, C. D.: Happiness is everything, or is it? Explorations on the meaning of psychological well-being. [Online]. Journal of Personality and Social Psychology, 57(6), 1989, 1069-1081. https://doi.org/10.1037/0022-3514.57.6.1069

15. Seymour-Rolls, Hughes, K..: Participatory action research: Getting the Job Done [Online]. Retrieved March 13, 2020, from http://www.aral.com.au/arow/rseymour.html. 1998.

16. Švamberk Šauerová, M.: Techniky osobnostního rozvoje a duševní hygieny učitele. Praha: Grada, 2018. Pedagogika. 280 p. ISBN 978-80-271-0470-3

17. Švaříček, R., Šed'ová, K. et al.: Kvalitativní výzkum v pedagogických védách. Praha: Portál, 2nd edition, 2014. 384 p. ISBN 978-80-262-0644-6.

18. Walker-Floyd, L. K.: A Narrative Study of how an Online Practitioner used a Personal Action Research Journal as a Form of Professional Development. Ann Arbor: ProQuest, 2011. 19. Willis, J., Edwards, C. L.: Action Research: Models, Methods, and Examples. Charlotte: Information Age Publishing, 2014. 332 p. ISBN 978-1-62396-655-3.

Primary Paper Section: A

Secondary Paper Section: AM 